\title{
Village Apparatus Competence, Individual Morality, Internal Control System and Whistleblowing System on Village Fund Fraud
}

\author{
SUGENG WAHYUDI ${ }^{1}$, TARMIZI ACHMAD ${ }^{1}$, IMANG DAPIT PAMUNGKAS $^{2 *}$ \\ ${ }^{1}$ Faculty Economics and Business, Universitas Diponegoro, \\ INDONESIA \\ 2*Faculty Economics and Business, Universitas Dian Nuswantoro, \\ INDONESIA
}

\begin{abstract}
The purpose of this research is to test and explain the influence of village apparatus competence, individual morality, internal control system, and whistleblowing system on the prevention of village fund fraud. This research is quantitative research with a descriptive research design. Sources of data in this study using primary data obtained from the results of distributing questionnaires to village officials in Sumowono District, Central Java, Indonesia with 99 respondents. The results of this study indicate that the competence of village officials, individual morality, internal control systems, and whistleblowing systems simultaneously have a significant effect on the prevention of village fund fraud. Partially, the competence of village officials, individual morality, internal control systems, and whistleblowing systems have a positive effect on the prevention of village fund fraud.
\end{abstract}

Key-Words: - Village Apparatus Competence, Individual Morality, Whistleblowing System, Village Fund Fraud.

Received: November 17, 2020. Revised: June 1, 2021. Accepted: June 18, 2021. Published: July 7, 2021.

\section{Introduction}

The objective of the village fund is basically to achieve inclusive economic growth by more equitable distribution of income. The funding priority referred to by the Central Government is a category of successful village fund management. The success of managing village funds can be reflected in Government Regulation Number 60 of 2014 article 19 paragraphs 1 and 2, namely that village funds are used to finance governance, development, community, and community empowerment. Furthermore, village funds in paragraph 1 are prioritized for community development and empowerment. Based on this, the indicators of the success of village funds can be seen from the success of development and improvement of community welfare through the empowerment of village communities. Since the enactment of Law No.6 of 2014 concerning Village Funds, Village Funds have resulted in APBN funds of Rp. 1 billion which can be started to be taken in stages in 2015. The Village Government has received Village State Budget funds directly from the central government which is used to develop villages. So, that each village must be responsible for reporting the funds.

Law No.6 of 2014 concerning villages has given authority to villages to regulate and manage all sources of village income as the responsibility of the village in meeting village needs and priorities. Village funds are sourced from the APBN allocated for villages. The APBN allocation for villages will always increase from year to year. Therefore, to realize development programs for villages in Indonesia and improve the welfare of rural communities, the government disburses large enough funds every year to be distributed to villages throughout Indonesia as stated in, namely starting from 2015-2019, the government budgeted village funds continued to increase every year from $\mathrm{Rp}$. 20.8 Trillion in 2015, Rp. 47 Trillion in 2016, Rp. 60 Trillion in 2017 \& 2018, Rp. 70 Trillion in 2019 and President Joko Widodo has declared that for 2020 the Village Fund Budget will reach Rp. 72 Trillion with a percentage increase of $2 \%$ from the previous year. A large amount of the village fund budget is expected to be able to advance the village through improving public services, increasing village and village resources not only as objects of development but also being the subject of development. The phenomenon of increasing the number of village funds disbursed by the government is not in line with good management.

[2] has been monitoring acts of corruption that occur in villages. The results of ICW monitoring, in 2015-2017 cases of corruption in the village 
increased. Corruption cases reached 17 cases in 2015 and jumped to 41 cases in 2016. A very significant increase occurred in 2017 with 96 cases. So that all identified cases of corruption totaled 154 cases. Of the 154 corruption cases, not all were corruption cases involving the APBDes. The number of cases with the APBDes object was 127 cases, while in a row there were 27 cases with objects, not the village budget or a total of $18 \%$ of the total cases. Illegal collection by village officials is a case with objects other than the APBDes. Meanwhile, the corruption cases related to APBDes consisted of corruption of Village Fund Allocation, Village Fund, Village Treasury, and others. The perpetrators of corruption in the village government have carried out various modes, most of which are budget misuse of 51 cases, 32 cases of embezzlement, 17 fictitious reports, 15 fictional activities or projects, and 14 cases of budget overruns. The surge in corruption in the village sector illustrates a poor record that is closely related to discussions on evaluating government policies for villages. All these corruption cases require that the village which is believed to be part of the development until now becomes a new field of corruption. APBDes that are corrupted and misused can have a very negative impact on the hope of increasing the welfare of rural communities and village development.

The individual morality of the employees can influence the tendency to village fund fraud. This can be said because, if someone has high morality he tends to have good integrity and is reluctant to break the rules even though at that time there is an opportunity to commit fraud. Good individual morality will prevent a person from committing fraud even under the greatest pressure. This can happen because if an individual is embedded in good morality and has good values and norms he will tend to avoid violating the rules. If an organization has a good ethical culture, it will create a good and virtuous work environment. A virtuous work environment will tend to encourage employees not to violate established rules and norms.

Phenomenon misuse of village funds is still frequent and tends to increase. Indonesia Corruption Watch recorded 454 total corruption cases that were prosecuted throughout 2018, of which 96 corruption cases were cases of misappropriation of the village fund budget. The consequences of the corruption case caused huge losses to the state up to Rp. 37.2 billion. Factors that can lead to fraud in village financial management based on the findings of the Corruption Eradication Commission include aspects of governance, aspects of supervision, and aspects of human resources, regulatory and institutional aspects. The reason for choosing the object of this research was because based on the results of initial interviews with Sumowono village officials stated that there was an increase and decrease in prices in village fund management planning as well as the existence of village apparatus staff who were concurrently assigned because there was still a lack of understanding from other village officials so that operational implementation was possible. There is fraud on the part of the management. In addition, in 2018 Semarang Regency experienced a decline in village fund receipts. So, this phenomenon becomes interesting when it is associated with the management of village funds and the potential for fraud. The benefit of this research for Sumowono Subdistrict is to provide an evaluation or input regarding potential fraud and anti-fraud strategies in managing village funds. Based on the explanation above, several factors are considered capable of influencing the prevention of village fund fraud. Based on the phenomenon of the gap and research gap, this research is interested in taking the title "The Effect of Individual Morality, Internal Control Systems and Whistleblowing Systems on the Prevention of Village Fund Fraud".

\section{Literature Review \\ 2.1 Agency Theory}

Agency theory aims to solve problems that often occur in agency relationships. The first problem that often arises in agency relationships is the difference in interests between agents and principals, this problem is caused by information asymmetry [3]. Information asymmetry can be defined as differences in information between agents and principals. In such agency theory, it can lead to a high tendency of fraud if there is no supervision and good morals. The tendency of fraud based on a theoretical perspective can be caused by opportunities, pressure, and rationalization or what is commonly called the fraud triangle [4]. The first branch of the fraud triangle is an opportunity. Opportunities in this research can be interpreted by the possibility of fraud in an entity. One of the opportunities for fraud in an organization can be caused by a weak internal control system. An effective internal control system can prevent potential offenders from committing fraud. Feels he will get caught if he commits an offense to the entity.

Fraud is a crime that can be handled in two ways, namely preventing and detecting, even fraud that is 
revealed is a small part of all fraud that occurs [5]. Fraud refers to the misrepresentation of material facts by one party to another intending to deceive and influence other parties to depend on these facts, facts that will harm them and based on applicable law. This lie has caused injustice or loss for victims of fraud [6].

\subsection{Village Fund}

The ratification of Law No.6 of 2014 concerning Villages on January 15, 2014, brought blessings to villages throughout Indonesia. The law, which has been in discussion for 7 years, regulates the source of funding for 73 thousand villages which comes from contributions from the central government and regional treasuries. According to the law, each village is allocated a large number of funds that can even reach one billion rupiahs per village. The Village Law provides a more certain guarantee that each village receives funds from the government through the state and regional budgets, which are many times higher, far above the amount currently available in the village budget. Although the value of one billion cannot be realized this year, at least the government has tried to keep its promise to carry out development evenly to remote villages. The Village Fund, which ranges from the hundreds of millions of rupiah, began to be disbursed in 2015 to all villages in Indonesia through the district, without deducting a dime. Even so, some village officials have not dared to take and take advantage of village funds that have entered village accounts. The absence of clear rules regarding the mechanism for collecting and using Village Funds caused them to feel worried about using these funds. Law No.6 of 2014 provides a more certain guarantee that each village receives funds from the government through the state and regional budgets, which are many times higher, far above the amount currently available in the village budget.

Village Finance is all village rights and obligations that can be valued in money and everything in the form of money and goods related to the implementation of village rights and obligations [7]. These rights and obligations give rise to income, expenditure, financing, and village financial management. Village finances are used by village officials to carry out village administration, implement village development, foster village communities, and empower village communities. Village finances include village rights and obligations that can be measured in money and everything in the form of money and goods that can be realized in village income in the form of village original income, state revenue and expenditure budget allocations, regional tax revenue sharing, and district/city regional retribution, fund allocation village, financial assistance from the provincial government and district/city government grants and non-binding donations from third parties as well as other legitimate village income [8].

\subsection{Individual Morality}

Morality is a principle and rule of decency in social life. Morality can be divided into individual morality, morality social and mondial morality. Individual morality is an awareness of good principles which is inward, embedded in humans which will affect the way of thinking and act. Morality arises from within, not by being forced from without. Morality is an attitude of the heart that is revealed in outward actions. Social morality is reflected of individual morality in seeing social reality, namely the way individuals see people others as human beings who have the same value and dignity. While morality mondial is morality that is universal and applies anywhere and anytime, related to justice, humanity, independence and so on.

Individual morality is a behavior or attitude in which a person doing something leads to positive or good things based on sincerity without asking for a reply. Someone who has a low level of moral reasoning has different behavior from people who have a low level of reasoning high morale if the person faces an ethical dilemma. According to [7] explain that morality occurs when people take the good because he is aware of obligations and responsibilities and not because he was looking for profit. Thing this can be interpreted that morality individual is attitude and behavior which is good, where the person is not asking in return or selflessly. Refers to theory development Kohlberg can be used to measure level of reasoning one's morals individual in behave in a organization and morality individual is whole principle and the value regarding well or awareness an employee to responsible an entity, value of honesty and ethics, obey every that rule happens inside entity and individual attitude in to do no action honest bad character as human.

\subsection{Village Apparatus Competence}

According to [9] competence is an adequate skill to perform a task or can be interpreted as a skill that is possessed and the ability that is implied. HR competency is the skills found in humans to face situations or circumstances when carrying out their job responsibilities. The competence of the village 
apparatus can be improved by covering several aspects, namely the ability to acquire knowledge, skills, and insights through learning, training, experience, and education. Therefore, the village apparatus is an important factor that greatly determines the success of the implementation of the tasks assigned to them [10]. Morality According to [11] morality is a good and bad attitude that a person or individual has. [12] states that morality arises when someone does good based on awareness of their obligations and responsibilities, and not because they want to get profit from something they do. This statement can be defined that the morality of everyone is good behavior or attitude, where the person acts selflessly or does not ask for anything in return.

\subsection{Internal Control System}

"Committee of sponsoring organization of the tread way commission (COSO) framework of internal control" defines the internal control system is a process carried out by the commissioners, management and personnel other entities designed to provide reasonable assurance about the achievement of three groups, namely the reliability of financial reporting, effectiveness and operating efficiency, as well as compliance with applicable penalties and regulations applies [13]. System internal control is one way to be able to supervision or monitoring of financial management. Because with system internal control if it is good then an organization will be able to run well. The implementation of the internal control system is integrated and becomes an integral part of the company activities. It is not a separate part of the activity, nor is it added to the activities that have been arranged. This is reflected in the existing components in the internal control system [14]. Control components are designed and implemented by management to provide reasonable assurance that objectives control has been achieved.

\subsection{Whistleblowing System}

The National Committee for Governance Policy states that whistleblowing is the disclosure of attitudes that violate or violate the law, inappropriate attitudes, or other attitudes that can harm other organizations or institutions that can take action for violations that have occurred. This disclosure is usually done confidentially. The disclosure must be made based on good faith and not a form of individual protest against the grievance procedure or based on bad intentions [15]. According to Pamungkas, Ghozali, \& Achmad,
(2017); Park, 2009; Wahyudi et al., (2019) whistleblowing is the delivery of information on actions that violate the law, regulations, procedures, and misuse of responsibility that can endanger the people. Pamungkas et al., (2017) define fraud as an abuse of authority/rank that occurs in the government sector which is carried out for the benefit of individuals. For example, the illegal sale of state assets by stakeholders, procuring kickbacks in the government sector, bribery, and theft of government funds. According to [19] fraud is all efforts made by a person using special skills to benefit from certain groups by carrying out wrong actions. [20], [21] argue that fraud is an illegal act that is deliberately carried out for the desired purpose, for example, committing fraud by providing misleading explanations/exposures for the benefit of individuals and/or communities in the wrong way and can harm other parties either directly or indirectly.

\subsection{Hypothesis Development}

\subsubsection{Competence of Village Apparatus affects the Prevention of Village Fund Fraud}

Competence is the ability possessed by each individual to carry out their duties and responsibilities in carrying out the work they are engaged in. Because the more someone has a high position in the organization, but the competence they have is inadequate, it does not rule out the possibility of cheating. This statement is supported by research conducted by [22], [23] proving that apparatus competence has a significant effect on the prevention of village fund fraud, the higher the competence of village officials, the higher the level of prevention. Fraud in the management of village funds. But the results of this study are not in line with the research conducted by [24], [25] which states that competence does not have a significant effect on accounting fraud.

[8] stated that the village does not understand the management of village funds and the condition of human resources who are not yet competent in managing village funds due to a lack of socialization and technical guidance. This practically makes the village unable to show accountability in managing village finances, especially in implementing computerized accounting. Even so, village officials have the enthusiasm to continue to succeed in the implementation of the village fund program from the central government, namely by increasing the number of physical programs to absorb village funds. Other research also states that accountability is positively related to budget management, in this case, the budget can be assumed to be the same as 
village finance whose management is budget-based. Competence of Human Resources is one of the important things in the success of the village law so that until now it has become a priority program of the central government to instruct each village to have experts in village financial management. The village government must prepare the best possible work system and skilled human resources and empower facilitators such as assistants who are mainly in financial management and information technology. With skilled human resources in the village and able to apply everything mandated by laws and other regulations concerning village funds, accountability for village financial management will be achieved so that all kinds of fraud are avoided.

H1: Village Apparatus Competence affects the Prevention of Village Fund Fraud

\subsubsection{Individual Morality affects the Prevention of Village Fund Fraud}

Morality is good/bad behavior that comes from within humans which can be influenced by the family and organizational environment. [26] stated that someone who upholds morality can avoid cheating because someone concerned with morals will tend to obey the norms that apply by ethical principles. Meanwhile, someone who does not uphold morality will make decisions of his own will and ignore the obligations and regulations that should be fulfilled. By instilling morality in each individual, it is hoped that it can prevent fraud. This statement is supported by research conducted by [27] that morality affects the prevention of fraud. However, the results of this study are not in line with research conducted by [12] which states that morality does not have a significant effect on the tendency of accounting fraud. Various empirical evidence suggests that fraud arises because it is influenced by 2 factors, namely internal and external. One of the internal factors that can cause fraud is individual behavior. Individual behavior can be a factor in the emergence of fraud [28]. This is because, if the individual has a bad temperament and morals, even if the internal control of an entity is effective, he will still look for loopholes. [11], [29] explains that the ethical behavior of a person is influenced by moral reasoning. A person with a low level of moral reasoning tends to behave that shows his beneficial behavior. Someone with morals will behave well and not only do it for his benefit but also generally. In the research of [12] explaining the high individual morality of a person, the individual will pay more attention to universal interests rather than individual interests and avoid committing a tendency to fraud.
H2: Individual Morality affects the Prevention of Village Fund Fraud

\subsubsection{Internal Control System affects the Prevention of Village Fund Fraud}

[30] states that internal control is a series of policies to protect the assets of an organization or company from fraud, guarantees the availability of accurate accounting information, and ensures that all statutory regulations have been implemented and obeyed by all organizational employees. Because the internal control system in an organization is getting better, it will prevent fraud because there is no opportunity, on the other hand, if the control system in an organization is not good, it will be an opportunity for the white-collar to commit fraud. This statement is supported by the research results of [27], which state that the internal control system has a positive effect on fraud prevention. But the results of this study are not in line with research conducted by [31] which states that the internal control system does not affect fraud prevention.

An internal control system is prepared by an entity to manage and identify risks. Establishing good and effective internal controls has become a hot issue because of the high number of fraud cases that have occurred at this time. Theft, embezzlement, and fraud can be prevented and minimized. [32] that fraud can be prevented by an effective internal control system. Fraud can be committed by offenders when they feel they have the opportunity, and the possibility of such fraud being revealed is small. According to [33] individuals often believe more in being able to hide their mistakes and can avoid punishment. Through a good and effective internal control system, it can prevent potential offenders from thinking that they will escape if they commit fraud. The results of research by [34] explain that if the effectiveness of the internal control system is high, the tendency for fraud will below.

H3: The Internal Control System affects the prevention of Village Fund Fraud

\subsubsection{Whistleblowing System affects the Prevention of Village Fund Fraud}

Whistleblowing system is the disclosure of information about fraudulent actions that occur in organizations carried out by individuals or groups that have an impact on the loss of the state or society with good goals for the common interest and not for personal gain. This statement is supported [7], [8], [24] stating that the whistleblowing system has a significant positive effect on fraud prevention. However, the research does not support the research conducted by [35] which states that the 
whistleblowing system has a negative and significant effect on the tendency of accounting fraud.

The rise of cases of financial embezzlement, asset manipulation, and village fund fraud prove that the supervision has not been maximal. This encourages the government to create community aspirations services named lapor.go.id and kpk.go.id to be able to report indications of irregularities that have occurred and as a form of corruption reduction and prevention measures. In addition to reporting directly to the authorities, reporting actions can be carried out internally by the company if implementing a whistleblowing system. The application of the whistleblowing system is considered quite effective so that many companies and organizations develop a whistleblowing system and apply it to the managed organization [18]. All parties involved in village finances must work together and be committed to cracking down on perpetrators of fraud and reporting them through the whistleblowing system with a mechanism in the village.

The results of research conducted by [23] state that the whistleblowing system has a significant effect on the prevention of village fund fraud. Research conducted by [34] shows that the weak elements of guidance and supervision of the subdistrict head, the Government and Development Security Escort Team, the Village Consultative Body, and the lack of Human Resources in managing village funds and village heads are the causes of the tendency to misuse village funds. [36] also researched the potential for fraud in village financial management which saw the potential for fraud in terms of regulation, governance, and supervision.

H4: Whistleblowing System affects the prevention of Village Fund Fraud

\section{Method}

This research is quantitative research with a descriptive research design. Sources of data in this study used primary data obtained from the results of distributing questionnaires to all village officials and village consultative bodies (BPD) as many as 99 respondents. This research was conducted in Sumowono Village, in Sumowono District. Questionnaire Design Researchers developed a questionnaire by adopting previous research and also developing their own referring to existing theoretical indicators. The questionnaire used will measure one dependent variable and two independent variables according to a predetermined research model. The scale used for measurement is the Likert scale which is stated in the range of numbers 1 to 5 .

\subsection{Research Object}

The population in this study were village officials who worked in the Subdistrict of Sumowono District and used a purposive sampling method as sampling by conducting a questionnaire distribution survey. This research was conducted to see the potential for village fund fraud and anti-fraud strategies in the management of village funds in Sumowono District, Semarang Regency. This study uses the object of village financial management by village officials in Sumowono Village, Sumowono District, Semarang Regency. Data Sources this study uses primary data which is obtained directly from authentic sources in the form of the opinion of one or more individuals. Data obtained directly from the Village Financial Management Technical Implementation.

Data collection techniques interview and observation techniques were used to obtain data in this study. This study uses a qualitative descriptive analysis technique, which provides an overview and description of the characteristics of the informants. The research begins with the researcher asking open questions to the speakers. The research begins with the researcher asking open questions to the speakers. After analyzing the data, the results of the informants' answers are processed and presented in the form of data. Open questions in interviews were used to dig deeper information about village financial management, as well as the potential for fraud that occurred in it. Methods in this study used was a survey research method, which was a study conducted on several sample members from a particular population. The data collection was carried out using a questionnaire consisting of a structured list of questions aimed at respondents. The data was taken in May-July 2020. Analysis tool the approach used in this study was the Partial Least Square (PLS) approach, which is a multivariate statistical technique that makes comparisons between multiple dependent and multiple independent variables with the analysis tool used is WarpPLS. The SEM method is based on a causal relationship, where changes in one variable have an impact on changes in other variables. PLS is a variant-based Structural Equation Model (SEM) statistical method designed to solve multiple regression when specific problems occur in data, such as small research sample sizes, missing values, and multicollinearity. 
As stated by [37] PLS is a powerful analysis method because it is not based on many assumptions. The data does not have to have a multivariate normal distribution (indicators with a category scale, ordinal, interval to ratio can be used in the same model), the sample does not have to be large [38].

Table 1. Convergent Validity and Internal Consistency Reliability

\begin{tabular}{|c|c|c|c|c|c|c|}
\hline Variable & Indicator & $\begin{array}{c}\text { Outer } \\
\text { Loading }\end{array}$ & $\begin{array}{c}\text { Average } \\
\text { Variance } \\
\text { Extracted } \\
\text { (AVE) }\end{array}$ & $\begin{array}{l}\text { Composite } \\
\text { Reliability } \\
\text { (CR) }\end{array}$ & VIF & $\begin{array}{c}\text { Cronbach' } \\
\text { s Alpha }\end{array}$ \\
\hline \multirow[t]{3}{*}{$\begin{array}{l}\text { Village Apparatus } \\
\text { Competence }\end{array}$} & VAC1 & 0,904 & 0,709 & 0,878 & 1,817 & 0,788 \\
\hline & VAC2 & 0,904 & & & & \\
\hline & VAC5 & 0,701 & & & & \\
\hline \multirow[t]{4}{*}{ Individual Morality } & IM1 & 0,894 & 0,765 & 0,929 & 2,370 & 0,897 \\
\hline & IM2 & 0,927 & & & & \\
\hline & IM3 & 0,846 & & & & \\
\hline & IM4 & 0,828 & & & & \\
\hline \multirow[t]{3}{*}{ Internal Control System } & ICS1 & 0,835 & 0,762 & 0,906 & 2,323 & 0,843 \\
\hline & ICS2 & 0,878 & & & & \\
\hline & ICS3 & 0,904 & & & & \\
\hline \multirow[t]{4}{*}{ Whistleblowing System } & WBS1 & 0,865 & 0,718 & 0,911 & 1,939 & 0,869 \\
\hline & WBS2 & 0,900 & & & & \\
\hline & WBS3 & 0,818 & & & & \\
\hline & WBS4 & 0,804 & & & & \\
\hline \multirow[t]{3}{*}{ Village Fund Fraud } & VFF1 & 0,835 & 0,762 & 0,906 & 2,112 & 0,843 \\
\hline & VFF2 & 0,878 & & & & \\
\hline & VFF3 & 0,904 & & & & \\
\hline
\end{tabular}

Source: Data processing result for WarpPLS 6.0, 2020

Table 2. Model Fit and Quality Indices

\begin{tabular}{lccc}
\hline \multicolumn{1}{c}{ Qualiy Indices } & Result & P-Value & Conclussion \\
\hline Average Path Coefficient (APC) & 0,277 & $\mathrm{P}=0,001$ & Fit Model \\
\hline Average R-squared (ARS) & 0,323 & $\mathrm{P}<0,001$ & Fit Model \\
\hline $\begin{array}{l}\text { Average Adjusted R-Squared } \\
\text { (AARS) }\end{array}$ & 0,315 & $\mathrm{P}<0,001$ & Fit Model \\
\hline Average Block VIF (AVIF) & 1,687 & acceptable if $<=5$, ideally $<=3,3$ & Fit Model \\
\hline $\begin{array}{l}\text { Average Full Collinearity } \\
\text { (AFVIF) }\end{array}$ & 1,891 & acceptable if $<=5$, ideally $<=3,3$ & Fit Model \\
\hline $\begin{array}{l}\text { Tenenhaus Gof (Gof) } \\
\text { Sympon's Paradox Ratio (SPR) }\end{array}$ & 0,575 & small $>=0,1$, medium $>=0,25$, large $>=$ & Fit Model \\
\hline R-Square Contribution Ratio (RSCR) & 0,859 & Acceptable if $>=0,7$, Ideally $=1$ & Fit Model \\
\hline $\begin{array}{l}\text { Statistical Suppression Ratio (SSR) } \\
\text { Non Linear Bivariate Causality } \\
\text { Direction Ratio (NLBCDR) }\end{array}$ & 0,842 & Acceptable if $>=0,9$, Ideally $=1$ & Fit Model \\
\hline $\begin{array}{l}\text { Source: Data processing result for WarpPLS 6.0 2020 } \\
\text { Acceptable if }>=0,7\end{array}$ & Fit Model \\
\hline
\end{tabular}




\section{Result and Discussion}

\subsection{Result}

Convergent Validity of the measurement model with a reflective indicator is assessed based on the correlation between the indicator score and the latent variable score/loading factor as measured by PLS. An individual reflective measure is said to be high if it correlates more than 0.70 with the latent variable to be measured. But according to [39], in the early stages of research developing a measurement scale a loading factor value of 0.5 to 0.60 is considered good enough. In this research, the initial stage of convergent validity shows that all indicators meet the requirements of convergent validity. In addition, in this study to measure convergent validity, it can be done by looking at the results of WarpPLS 6.0 in the Average Variance Extracted (AVE) section. This AVE measurement describes the variance or variety of manifest variables that can be contained by latent variables. The assessment criterion is an AVE value> 0.5 [40].

The results Table 1 . show satisfactory composite reliability of each construct, namely: Village Apparatus Competence (0.709), Individual Morality (0.929), Internal Control System $(0,835)$, Whistleblowing System (0.911), Village Fund Fraud (0.906). The results of Cronbach's Alpha also showed good results, namely Village Apparatus Competence (0.788), Individual Morality (0.897), Internal Control System $(0,843)$, Whistleblowing System (0.869), Village Fund Fraud (0.843). It can be concluded that each construct has high reliability, which can be seen from the composite reliability value and Cronbach's alpha of all constructs greater than 0.70. The Next Step is the evaluation of the Structural Model (Inner Model). This fit model test is used to determine whether a model has a fit with the data. In this model fit test, there are 3 test indices, namely the average path coefficient (APC), average R-squared (ARS), and average variances factor (AVIF) with the APC and ARS criteria accepted with the condition p-value $<0.1$ and AVIF is less than 5. Based on the Test Results of Table 2 Analysis. Testing Model Fit and Quality Indices, this study states that the conclusion is Model Fit and ready for further testing.

\subsection{Discussion}

\subsubsection{Village Apparatus Competence on Village Fund fraud}

The ability of the apparatus and the internal control system greatly affects the prevention of fraud in village financial management [23]. [41] conducted research related to the potential for misuse of village fund allocation financial management. Meanwhile, the results of other studies show that village financial management in Indonesia has a worrying potential for fraud in every process [8], [42]. The implementation of village financial management in Indonesia is a new government program as a manifestation of regional autonomy so that not much research has been carried out, especially research related to fraudulent village financial management. All villages in Indonesia are expected to be able to apply the village financial system application (siskeudes) as technology development to prevent unwanted cheating. Control to prevent this potential fraud is to increase the moral and ethical values of all village officials so that they have more integrity. Village officials are expected to have good integrity and not justify fraudulent acts committed with increased morale and ethical changes [43]. The potential for further fraud is negligence that is unconsciously committed by village officials which will harm other parties. Fraud tends to occur because of the attitude of the perpetrator who makes mistakes while harming other parties or organizations. At the stage of implementing village financial management by the Head of Finance, he was negligent in paying taxes because he did not understand tax payments so that village officials had to cover the shortage of payments using funds from community groups. The results of this study are by research conducted by [44] which states that apparatus competence has a significant effect on the prevention of fraud in village fund management, where the higher the competence of village officials, the higher the level of fraud prevention management of village funds.

\subsubsection{Individual Morality on Village Funds Fraud} Based on the results of this study, the second hypothesis is accepted, this means that the empirical data supports the hypothesis that morality affects the prevention of fraud in the management of village fund. Sig value. The variable for morality is $<0,001$. Because the significance level is $<0.05$, the morality variable has a positive effect on fraud prevention in village fund management in Sukoanyar Village, Wajak Village, Sukolilo Village, Blayu Village, and Patokpicis Village. The results of this study are consistent with the research conducted by [27] which states that morality has a positive effect on fraud prevention in village financial management. The results of this study are supported by Kohlberg's theory of moral development which is explained by [45] that there are several stages of moral development including the conventional and postconventional stages. Whereat the pre-conventional 
stage or the lowest stage it is explained that the actions taken by individuals are based on fear of applicable laws or regulations, and at the postconventional stage or the highest stages it is explained that the actions taken by the individual are based on universal laws. Anyone at any time can commit fraud.

One of the red flags in fraud is abused of power. Abuse of power or authority is the starting point for fraud. The village head has the authority to administer Village Administration, carry out Village Development, Village community development, and empower Village communities. The Village Head has full rights over the use of the village budget. So, it is prone to misappropriation of Village funds if the control system, supervision, is not running well. Fraud Diamond Theory was first presented by [46] in the journal CPA in December 2004. This version is seen as an extended version of the Fraud Triangle Theory. In this theory, a new element is added that fulfills the three components of the Fraud Triangle Theory called Capability. [46] argue that although the perceived pressure may coincide with Opportunity and Rationalization, it is unlikely that cheating will occur if the fourth element (ability) is not present. In other words, potential perpetrators must have the skills and abilities to commit fraud [47]. If someone has high morality he tends to have good integrity and is reluctant to break the rules even though at that time there is an opportunity to commit fraud.

\subsubsection{Internal Control System on Village Fund Fraud}

The internal control system does not affect the accountability of village fund management. This is because the village government is an autonomous region so that it does not understand the importance of implementing and maintaining effective internal control which is the responsibility of all parties. Community participation affects village fund management accountability. The conclusion is that in creating good governance requires the involvement of the community to convey their aspirations and contributions in the preparation of the APBDes. With the contribution or participation of the community in the preparation of the APBDes, it will be more focused and good so that the community is active in driving program activities. Apparatus competence affects the accountability of village fund management. This shows that the higher the competence of the apparatus, the higher the accountability of village fund management. Human accountability affects the prevention of fraud in the management of village funds. This means that accountability is needed to prevent all abuses in the Village Government in managing village funds. Opportunities to commit fraud can arise because of loopholes in control weaknesses to prevent and detect violations. Good internal controls can prevent potential fraud.

Based on the results of this study, the third hypothesis which states that the internal control system affects the prevention of misappropriation of village funds is accepted. The sig value of the internal control system variable $<0.001$ which proves that the internal control system has a positive effect on preventing fraud in the management of village funds in Duren Village, Keseneng Village, Ngadikerso Village, Bumen Village, and Pledokan Village in Sumowono District, and the effect. This is also significant, meaning that if the internal control system in the villages of Kemitir Village, Mendongan Village, Jubelan Village, Kemawi Village, and Trayu Village is improved again, it will be able to increase fraud prevention in the management of village funds.

\subsubsection{Whistleblowing System on Village Fund Fraud}

The results of this study indicate that the fourth hypothesis which states that whistleblowing has an effect on fraud prevention in managing village funds is accepted. This is evidenced by the value of sig. The whistleblowing variable is 0.000 , which means that whistleblowing has a positive effect on fraud prevention in the management of village funds in Sukoanyar Village, Wajak Village, Sukolilo Village, Blayu Village, and Patokpicis Village, Wajak District. Similarly, the variables X1, X2, and X3 on the whistleblowing variable have a significant effect, meaning that the higher a person's intention to do whistleblowing, the higher the level of fraud prevention in managing village funds. The results of this study are in line with research conducted by Bernardin and Solihat which states that whistleblowing has a significant positive effect on fraud prevention. [48] also stated that one of the whistleblowing efforts is to report by members of the organization, both active and inactive members regarding violations, illegal or immoral actions against the organization, both inside and outside the organization outside.

This method is used to find, minimize, and then eliminate violations or fraud by internal parties within the organization. The simultaneous test results on the variables of village apparatus competence, morality, internal control system, and whistleblowing show that together they have a simultaneous influence on fraud prevention in the 
management of village funds. This can be seen from the table of the results of hypotheses testing analysis which shows the Adjust R-square value of 0.648. This proves that fraud prevention is influenced by the competence of village officials, morality, internal control systems, and whistleblowing $64.8 \%$, and the remaining $36.2 \%$ is influenced by other variables outside the research. The results of this study indicate that the presence of competent village apparatus competence, high morality, and improved internal control system, and higher whistleblowing actions in an organization can provide prevention against fraud, which means that the opportunity to commit fraud is smaller or even absent.

Table 3. Relationship between Variables (Hypothesis Testing -> Sig. 5\% one-tailed)

\begin{tabular}{clccccc}
\hline Hypotheses & \multicolumn{1}{c}{ Relationship } & $\begin{array}{c}\text { Path } \\
\text { Coefficients }\end{array}$ & $\begin{array}{c}\text { Standard } \\
\text { Error }\end{array}$ & P-Value & $\begin{array}{c}\text { (R2) } \\
\text { Sig. Direct } \\
\text { Effect }\end{array}$ \\
\hline H1 & $\begin{array}{l}\text { Village Apparatus } \\
\text { Competence } \\
->\text { Village Fund Fraud }\end{array}$ & $-0,049$ & 0,095 & 0,042 & Accepted \\
\hline H2 & $\begin{array}{l}\text { Individual Morality } \\
->\text { Village Fund Fraud }\end{array}$ & $-0,292$ & 0,089 & $<0,001$ & Accepted \\
\hline H3 & $\begin{array}{l}\text { Internal Control System } \\
\text {-> Village Fund Fraud }\end{array}$ & 0,583 & 0,082 & $<0,001$ & Accepted \\
\hline H4 & $\begin{array}{l}\text { Whistleblowing System } \\
->\text { Village Fund Fraud }\end{array}$ & $-0,212$ & 0,091 & 0,010 & 0,648 & Accepted \\
\hline
\end{tabular}

\section{Conclusion}

This research is expected to be an input for the village government to improve the internal village office and follow up on reporting of fraud. Implications Based on the results of this study, the following implications are stated: Selection of competent village apparatus acceptance can affect fraud prevention in the management of village funds. For officials who have competency below the standard/average, the difference will be seen from village officials who have high competence or are above the set standards. Individual morality influences preventing fraud in the management of village funds. because individuals who have high morality will tend to stay away from actions that can harm themselves, society, organizations, and the state. The results of this study are used as input for the village head to further improve the competence of village officials, morality, internal control systems, and whistleblowing to minimize or even eliminate the occurrence of fraud because it will increase the prevention of fraud, especially in the management of village funds. This study has limitations, namely the lack of previous research on the factors that influence trust in leaders, besides that this research has not involved the Village Supervisory Agency. So that the potential for disclosing fraudulent management of village funds is only seen from the side of village officials and local neighborhoods. Suggestions The researchers' suggestions for the company in the future are:
Further research methods can use the interview method to strengthen research evidence. Adding other variables in this study, such as motivation and organizational culture. For further research can develop a qualitative approach. So that it can explore more deeply about fraud in village funds, they can expand the population not only in one village but several villages in one city or province so that it can be more generalized.

\section{Acknowledgment:}

This article is the result of research financed by Penelitian Dasar, DRPM DIKTI, Indonesia Year 2020. No: 257-02/UN7.6.1/PP/2020.

\section{References:}

[1] Law No.6 of 2014, "tahun 2014 tentang Desa." .

[2] I. C. Watch, "The Trend of Corruption Cases in 2017." Jakarta. Retrieved from https://antikorupsi. org/sites/default/files, 2017.

[3] M. Park and S. Chai, "The Effect of Information Asymmetry on Investment Behavior in Cryptocurrency Market," Proc. 53rd Hawaii Int. Conf. Syst. Sci., vol. 12, no. 1, pp. 149-158, 2020, doi: 10.24251/hicss.2020.494.

[4] V. N. Alviani, A. Kurniawan, and B. Sugiharto, "the Influence of Academic 
Pressure, Opportunity of Cheating and Rationalization of Cheating on the Behavior of Academic Cheating With Perception of Accounting Ethics As a Moderating Variable (on Stie Sutaatmadja Subang Accounting Students)," JASS (Journal Account. Sustain. Soc., vol. 1, no. 1, p. 48, 2019, doi: 10.35310/jass.v1i01.69.

[5] P. K. Gupta and S. Gupta, "Corporate frauds in India - Perceptions and emerging issues," J. Financ. Crime, vol. 22, no. 1, pp. 79-103, 2015, doi: 10.1108/JFC-07-2013-0045.

[6] Association of Certified Fraud Examiners, "Report to the Nation on Occupational Fraud \& Abuse," Glob. Fraud Study, pp. 1-92, 2016.

[7] I. Ghozali, T. Achmad, and I. D. Pamungkas, "Determinants of fraudulent financial reporting and whistleblowing system: Applying theory of planned behavior," WSEAS Trans. Bus. Econ., vol. 16, pp. 393-402, 2019.

[8] S. Wahyudi, T. Achmad, and I. D. Pamungkas, "Whistleblowing System and Fraud Early Warning System on Village Fund Fraud: The Indonesian Experience," Int. J. Financ. Res., vol. 10, no. 6, p. 211, 2019, doi: 10.5430/ijfr.v10n6p211.

[9] M. Pasban and S. H. Nojedeh, "A Review of the Role of Human Capital in the Organization," Procedia - Soc. Behav. Sci., vol. 230, no. May, pp. 249253, 2016, doi: 10.1016/j.sbspro.2016.09.032.

[10] D. Rahayu, A. Rahmayati, and D. Narulitasari, "Determinan Pencegahan Fraud Pengelolaan Keuangan Desa," $J$. Ilm. Among Makarti, vol. 11, no. 22, pp. 97-107, 2018.

[11] F. Fernandhytia and M. Muslichah, "The Effect of Internal Control, Individual Morality and Ethical Value on Accounting Fraud Tendency," Media Ekon. dan Manaj., vol. 35, no. 1, p. 112, 2020, doi: 10.24856/mem.v35i1.1343.

[12] S. Setiawan, "the Effect of Internal Control and Individual Morality on the
Tendency of Accounting Fraud," Asia Pacific Fraud J., vol. 3, no. 1, p. 33, 2018, doi: 10.21532/apfj.001.18.03.01.04.

[13] J. Lutz, "Committee of sponsoring organizations of the treadway commission: Internal control; integrated framework mit besonderer berücksichtigung der änderungen in der neuauflage 2013," 2015.

[14] E. S. Mardjono, Y. S. Chen, and L. J. He, "Earning management and the effect characteristics of audit committee, independent commissioners: Evidence from indonesia," Int. J. Bus. Soc., vol. 21, no. 2, pp. 569-587, 2020, doi: 10.5430/rwe.v11n3p108.

[15] T. Tuanakotta, "M. 2010," Akunt. Forensik dan Audit. Investig. Lemb. Penerbit Fak. Ekon. Univ. Indones. Jakarta, 2010.

[16] I. D. Pamungkas, I. Ghozali, and T. Achmad, "The effects of the whistleblowing system on financial statements fraud: Ethical behavior as the mediators," Int. J. Civ. Eng. Technol., vol. 8, no. 10, pp. 1592-1598, 2017.

[17] H. Park, "Park , H . and Blenkinsopp , J . ( 2009 )' Whistleblowing as planned behavior - A survey of South Korean police officers ', Journal of Business Ethics , 85 ( 4 ), pp . 545-556. Whistleblowing as Planned Behavior - a Survey of South Korean Police Officer," vol. 85, pp. 545-556, 2009.

[18] I. D. Pamungkas, I. Ghozali, and T. Achmad, "The effects of the whistleblowing system on financial statements fraud: Ethical behavior as the mediators," International Journal of Civil Engineering and Technology, vol. 8, no. 10. pp. 1592-1598, 2017, [Online]. Available:https://scholar.google.com/cita tions?view_op=view_citation\&hl=en\&us er=_BMTaskAAAAJ \&pagesize $=100 \&$ cit ation_for_view=_BMTaskAAAAJ:9yKS N-GCBOIC.

[19] W. S. Albrecht, C. O. Albrecht, C. C. Albrecht, and M. F. Zimbelman, SIXTH EDITION, Secth edit. Centre for 
Promoting Ideas, USA, 2019.

[20] T. Achmada, I. Ghozali, I. D. Pamungkas, U. Diponegoro, and U. D. Nuswantoro, "Detection of Academic Dishonesty: A Perspective of the Fraud Pentagon Model," vol. 13, no. 12, 2020.

[21] W. Shi, B. L. Connelly, and R. E. Hoskisson, External corporate governance and financial fraud: cognitive evaluation theory insights on agency theory prescriptions, vol. 38, no. 6. 2017.

[22] M. Chabachib, H. Hersugondo, E. Ardiana, and I. D. Pamungkas, "Analysis of Company Characteristics of Firm Values: Profitability as Intervening Variables," International Journal of Financial Research, vol. 11, no. 1. 2020, [Online]. Available: https://scholar.google.com/citations?view _op=view_citation\&hl=en\&user=_BMTa skAAAAJ\&pagesize $=100 \&$ citation_for view=_BMTaskAAAAJ:roLk4NBRz8U C.

[23] A. T. Atmadja, K. A. K. Saputra, and D. T. H. Manurung, "Proactive fraud audit, whistleblowing and cultural implementation of tri hita karana for fraud prevention," 2019.

[24] B. D. Handayani, A. Rohman, A. Chariri, and I. D. Pamungkas, "The dynamics of the political environment in the disclosure of local government financial statements: An insight from Indonesia," Int. J. Innov. Creat. Chang., vol. 11, no. 8, pp. 94-109, 2020.

[25] H. Umar, E. Erlina, and A. Fauziah, "Audit quality determinants and the relation of fraud detection," Int. J. Civ. Eng. Technol., vol. 10, no. 3, 2019.

[26] P. G. Lewellyn and L. C. Rodriguez, "Does Academic Dishonesty Relate to Fraud Theory? A Comparative Analysis," Am. Int. J. Contemp. Res., vol. 5, no. 3, pp. 1-6, 2015, [Online]. Available:

http://www.aijcrnet.com/journals/Vol_5_ No_3_June_2015/1.pdf.

[27] P. S. P. Laksmi, "Whistleblowing System, Competence, Morality, and
Internal Control System Against Fraud Prevention on Village Financial Management in Denpasar I Ketut Sujana1 Fakultas Ekonomi dan Bisnis Universitas Udayana, Indonesia," $J$. Akunt., vol. 30, no. 11, pp. 2780-2794, 2020.

[28] L. A. Nwanyanwu, "Accountants' ethics and fraud control in Nigeria: the emergence of a fraud control model," 2018.

[29] W. N. Adger, C. Butler, and K. WalkerSpringett, "Moral reasoning in adaptation to climate change," Env. Polit., vol. 26, no. 3, pp. 371-390, 2017.

[30] N. H. Uswati Dewi, D. Djuwito, and R. Wilopo, "The role of auditor in whistleblower system: The cases in Indonesia," J. Econ. Bus. Account. Ventur., vol. 18, no. 2, p. 301, 2015, doi: 10.14414/jebav.v18i2.456.

[31] S. A. Irwandi, I. Ghozali, Faisal, and I. D. Pamungkas, "Detection fraudulent financial statement: Beneish m-score model,"WSEAS Trans. Bus. Econ., vol. 16, no. May, pp. 271-281, 2019.

[32] N. Husnawati, L. Handajani, "Accounting Fraud: Determinant, Moderation of Internal Control System And The Implication To Financial Accountability," E-Proceeding Stie, no. 60, pp. 311-335, 2017, [Online]. Available: $\quad$ http://jurnal.stiemandala.ac.id/index.php/eproceeding/arti cle/view/139/0.

[33] M. C. Jensen, "Journal of Social and Personal," J. Soc. Pers. Relatsh., 1986.

[34] I. G. C. Putra, P. W. Saitri, and I. G. B. N. Gunadi, "Accounting Fraud Tendency on Village Credit Institution," Int. J. Account. Financ. Asia Pasific, vol. 2, no. 2, 2019.

[35] N. W. Rustiarini and N. M. Sunarsih, "Factors influencing the whistleblowing behaviour: A perspective from the theory of planned behaviour," Asian J. Bus. Account., vol. 10, no. 2, pp. 187-214, 2017.

[36] I. K. R. Setiabudhi and I. P. R. A. Putra, "Surveillance Urgency to Prevent Village 
Fund Corruption," J. Magister Huk. Udayana (Udayana Master Law Journal), vol. 9, no. 3, pp. 464-481, 2020.

[37] I. Ghozali, "Aplikasi Analisis Multivariate dengan Program IBM SPSS 21: Update PLS Regresi. Semarang." 2016.

[38] I. D. Pamungkas, I. Ghozali, T. Achmad, M. Khaddafi, and R. Hidayah, "Corporate governance mechanisms in preventing accounting fraud: A study of fraud pentagon model," J. Appl. Econ. Sci., vol. 13, no. 2, 2018.

[39] W. W. Chin, "Commentary: Issues and opinion on structural equation modeling." JSTOR, 1998.

[40] J. F. Hair, M. Celsi, D. J. Ortinau, and R. P. Bush, Essentials of marketing research, vol. 2. McGraw-Hill/Irwin New York, NY, 2010.

[41] S. Hasnan, R. A. Rahman, and S. Mahenthiran, "Management motive, weak governance, earnings management, and fraudulent financial reporting: Malaysian evidence," J. Int. Account. Res., vol. 12, no. 1, pp. 1-27, 2013.

[42] M. P. Sari, Kiswanto, L. V. Rahmadani, H. Khairunnisa, and I. D. Pamungkas, "Detection fraudulent financial reporting and corporate governance mechanisms using fraud diamond theory of the property and construction sectors in Indonesia," Humanit. Soc. Sci. Rev., vol. 8, no. 3, pp. 1065-1072, 2020, doi: 10.18510/HSSR.2020.83109.

[43] S. S. Halbouni, N. Obeid, and A. Garbou, "Corporate governance and information technology in fraud prevention and detection: Evidence from the UAE," Manag. Audit. J., vol. 31, no. 6-7, pp. 589-628, 2016, doi: 10.1108/MAJ-022015-1163.

[44] T. E. Ardiana, "The Influence Of Financial Reporting Compliance, Government Personnel Competency Towards Fraud Prevention In Village Fund Management"(Case Study In Kecamatan Siman Kabupaten Ponorogo)," Int. J. Econ. Bus. Account.
Res., vol. 4, no. 4, 2020.

[45] S. Iqbal and M. Sholihin, "The role of cognitive moral development in tax compliance decision making," Int. J. Ethics Syst., 2019.

[46] D. T. Wolfe and D. R. Hermanson, "The fraud diamond: Considering the four elements of fraud," 2004.

[47] R. Abdullahi and N. Mansor, "Fraud prevention initiatives in the Nigerian public sector," J. Financ. Crime, 2018.

[48] H. Mande, M. Mediaty, A. H. Habbe, and K. Kartini, "Level or Fraud and Professional Skeptisism to Become a Whistleblower."

\section{Author Contributions:}

Wahyudi, Sugeng Ideas; formulation or evolution of overarching research goals and aims.

Achmad, Tarmizi Development or design of methodology; creation of models.

Pamungkas, Imang Dapit has organized and executed Preparation, creation and/or presentation of the published work, specifically writing the initial draft (including substantive translation) and Making tables and discussing and updating references, corresponding author

This article is the result of research financed by Penelitian Dasar, DRPM DIKTI, Indonesia Year 2020. No: 257-02/UN7.6.1/PP/2020.

\section{Creative Commons Attribution}

\section{License 4.0 (Attribution 4.0 International , CC BY 4.0)}

This article is published under the terms of the Creative Commons Attribution License 4.0 https://creativecommons.org/licenses/by/4.0/deed.en US 